subjects that can be 'televised'. Television is a new art and has new principles connected with it. The substantial facts on which it is based are well known and the keen amateur is doing not a little to push it forward. This exhibition showed how much has been done in this respect, and also how much is being done by great corporations with large resources.

Ir is, however, necessary that the ideas of the public on television should not beturned in the wrong direction by exaggerated or imaginary statements as to its real and possible achievements, because then only disappointment results when the true facts are known. "We cannot yet televise directly a cricket match at Lords or a Cup football contest at the Crystal Palace. But what we can do is to take on a moving film with a camera certain not very quickly moving objects of large size and televise this film. There is an immense field in this respect for educational work. The Latin poet Horace told us, what every advertiser knows well, namely, that memory of the eye is more tenacious than memory through the ear. We can televise geometrical diagrams, lessons in botany, physics, and zoology, and countless other useful visions. Let us hope that this new weapon science has provided will not be vulgarised or put to base uses, but employed for the instruction, elevation and national entertainment of the public at large."

\section{Eugenics and Marriage Laws}

IN a note contributed to the Bulletin of Hygiene for February, Lettin M. Crump discusses the introduction of pre-marital health certificates from the point of view of eugenics. In Mexico, impediments to marriage include insanity, and similar restrictions extending to imbecility or feeblemindedness are found in certain of the United States. The growing practice of requiring a certificate from a qualified medical practitioner for insurance purposes, as well as from candidates for public appointments, seems likely to undermine opposition on this score, and with a more enlightened public opinion the need for compulsion would be greatly lessened. In some countries, notably Austria, Germany and some of the United States, the establishment of centres for giving advice on all matters concerning marriage has found favour. Useful advice can only be given when the investigator has a knowledge of the applicant's physical and mental condition as well as of his hereditary background and that of his proposed partner, the type of inheritance of any heritable disease or defect which may be present in the pedigree and of the effect which other causes may have upon the appearance of such heritable conditions. Mendelism provides us with a growing body of available information concerning inheritance in man, and evidence collected in the working of marriage advice bureaux leads to the conclusion that feeblemindedness is in many cases inherited and usually behaves as a recessive; the mating of possible heterozygotes is undoubtedly to be discouraged. Although evidence collected from pedigrees is frequently both vague and faulty, justice demands that every available means of making public such information as exists should be fully used so as to enable the conscientious citizen to avoid handing on defects from generation to generation.

\section{Anthropological Teaching and Research in Australia}

Tex passing of a resolution by the Australian and New Zealand Association for the Advancement of Science at its meeting at Sydney in August last, urging upon the Government the need for anthropological training for all white people who hold positions of authority or control over natives, has moved Prof. Raymond Firth to open the new volume of Oceania (vol. 3, pt. 1) with a survey of the progress of anthropology in Australia in the period 1926-32. The choice of this period as the limit of his survey is determined by the fact that its beginning coincides with the setting up of a Department of Anthropology in the University of Sydney and the appointment of Prof. A. Radeliffe-Brown to the chair, as the result of a resolution passed at the Australian meeting of the Pan-Pacific Congress in 1923. At the same time, a comprehensive scheme of research was initiated under the direction of the Committee for Anthropological Research of the Australian National Research Council, for which funds have been generously provided by the Rockefeller Foundation. In what has been accomplished, much has been due to Prof. Radcliffe-Brown, who, in virtue of his position in the University of Sydney and on the Research Council, has acted as a link in bringing closely together teaching and research. Investigation has been directed to both human biology and social anthropology. Not only has the work of Spencer and Gillen in central and northern Australia been continued and extended, but Prof. Radcliffe-Brown and others have also conducted investigations in areas in the east and the west of the continent. In looking forward, Prof. Firth sees that much virgin soil has to be explored, not only in Australia, but also in New Guinea and Melanesia; but in the first-named, he points out, there is need for haste lest the material vanish.

\section{Racial Distributions in Palæolithic Europe}

IN some 'notes' contributed to the Proceedings of the Prehistoric Society of East Anglia (vol. 7, pt. 1) Mr. M. C. Burkitt offers some interesting suggestions as to the possibly dual origin of the races and cultures of palæolithic age in Europe. He points out that it is no longer possible to accept the unfailing regularity of the sequence of cultures as originally classified by the French archæologists, and points to the contemporary existence, as proved by the fossil fauna, of a core industry, the coup de poing of ChelleoAcheulean times, on the west bank of the Rhine and of flake industries on the east bank, the two intermingling on the border line in eastern France, in southern Belgium and in Britain as seen in the Levallois and Clactonian industries. He goes on to point out that, while the coup de poing does not occur east of the Rhine with a few exceptions, the flake industry can be traced, except for certain gaps, from east of the Rhine right across Europe and Asia 
to China, where perhaps it finds its prototype in the flake implements of Peking man. This, to his mind, suggests a dual origin for the races of early palæo. lithic Europe, one branch coming from Africa where the coup de poing occurs with some frequency, and the second bringing the flake industry from Asia. He applies the same argument to Aurignacian man, pointing out that while the female statuette of upper palæolithic date has never been found in Africa, it occurs in Russia and examples have recently been found so far east as Maltá in Siberia. As the African affinities of Aurignacian man, or rather of his culture are not to be questioned, Europe would again in this period represent the point of confluence of two streams of migration.

\section{Prof. A. Stoll's Researches in Biochemistry}

THE biochemists in Germany publish their results in the Biochemische Zeitschrift, and some ten thousand original papers have been published in it in the past twenty-six years. The American and British work has been even more fruitful, at least in quality, during this period, so that there is little wonder that we are beginning to make progress in unravelling both the nature and structure of the substances found in the living cell and in understanding something of the reactions which take place there. Prof. Arthur Stoll of Basel has recently put together, for the purpose of a lecture, his own experiences since 1909 in developing some sections of biochemistry ("Ein Gang durch biochemische Forschungsarbeiten", pp. $41+5$ plates. Berlin : Julius Springer, 1933. 3 gold marks), much as in another walk of life a traveller might do on his return from a lengthy journey. Stoll began research with Willstätter and the chlorophyll molecule, and he returns to it at the end of his journey, for it has not yet given up all its secrets. In the meantime he has concerned himself with ergot, with scillarin, and with the digitalis glycosides. His pamphlet, which is illustrated, makes attractive reading: we concern ourselves too much nowadays with the abstruse intricacies of our sciences, and would be well advised to view them occasionally from a wider angle.

\section{Reopening Limestone Oil Wells with Acid}

THE natural flow of an oil well may recede either from the exhaustion of the oil supply or as the result of a stoppage of the pores of the oil-bearing rock cutting off the free supply of oil. In the past, somewhat drastic methods have been tried to overcome this drawback, but they are difficult to carry out, especially at a depth which may be half a mile below the surface. When the well is in a limestone forma. tion, it has now been discovered that it is possible to open it up again by treatment with successive quantities of 10 or 15 per cent hydrochloric acid, which dissolve new channels in the calcareous rock and permit of a new flow of oil. The use of hydrochloric acid is only made possible by the addition to it of 1-5 per cent of an arsenic compound, which inhibits the action of the acid on the metallic casing and pump tubes of the well. Other inhibitors, including certain organic nitrogen bases, have been discovered but the arsenic compounds are the most convenient to apply in practice. The discovery has been made by the Dow Chemical Co. in partnership with the Pure Oil Co., and patented as the Dowell process : it is described in greater detail in the News Edition of Industrial and Engineering Chemistry for February 20. The use of acid made inactive towards metal surfaces is a novel and important one : it may be a revolutionary factor in oil production. Further, it is likely to be beneficial in natural gas production and in other directions. It is certainly an achievement to be able to control the action of a strong acid as a boring agent half a mile below the surface.

\section{Petroleum Production in Russia}

According to Science Service of Washington, D.C., the petroleum production of Soviet Russia has now attained the position of being the second largest in the world, the estimated yield last year being 150 million barrels. Many factors have conduced to this remarkable advance, but chiefly the confiscation of oil property and its operation under Government directorship without competition have been responsible. The fields have the additional advantage that they are well situated for transport of oil to foreign markets and they are also easy to develop and operate. Another factor in the situation is the results of exploratory work, which have indicated the existence of potential oilfields along a tract of country stretching from the Arctic Ocean to the Caspian Sea. From the point of view of economics, as emphasised by Mr. R. C. Beckstrom to the American Institute of Mining and Metallurgical Engineers recently, Russia's home consumption is based mainly on industrial development and particularly on the extensive use of tractors for agricultural purposes, while external markets for oil lie chiefly with Italy, France and England, to which more than forty million barrels were exported last year. If the ambitious goal of more than 480 million barrels of oil production for 1937 is realised by the Soviet authorities, then clearly the whole scheme of international stability, in so far as petroleum supplies are concerned, will receive a severe shock.

\section{Institution of Heating and Ventilating Engineers}

THE Institution of Heating and Ventilating Engineers of 12, Russell Square, W.C.1, now issues a Journal, the first number of which was published in March. The object of the Journal is to keep its members in touch with the latest practice both at home and abroad and in particular to give them the latest results of the research work being done on the subject. In the first issue, an important paper by $\mathrm{E}$. Herring is published giving the methods that have been employed for warming and ventilating the Masonic Peace Memorial building in Great Queen Street, London, W.C.2. As many masonic meetings will be held there, it was necessary to use special precautions so as to eliminate the possibility of sound being transmitted from one room to another. All the fans, motors, and machinery had to run silently and it was necessary that the rate of ventilation and 